\title{
The Lower Extremity Ulcer, Mimicking Vascular Symptoms Due to Essential Thrombocythemia
}

\author{
Esansiyel Trombositemiye Bağlı Vasküler Semptomları Taklit Eden Alt Ekstremite Ülseri
}

Fatih Ada, Evren Özçınar, Sadık Eryılmaz, Mehmet Çakıcı, Mustafa Bahadır İnan, Levent Yazıcıoğlu, Nur Dikmen Yaman, Fatih Gümüș, Adnan Uysalel

Ankara Univeristy School of Medicine, Department of Cardiovascular Surgery

Received : July 09,2014 • Accepted: Dec 05,2014

Corresponding Author

Dr. Fatih ADA

Tel: 03125956139

E-mail: drisland58@hotmail.com

Ankara Univeristy School of Medicine, Department of Cardiovascular Surgery, 06590 Cebeci / Ankara

Lower extremity ulcers, especially those attributed to diabetes, venous disease or arterial disease comprise a substantial proportion of chronic ulcers. Meanwhile essential thrombocythemia is a rare component for the nonhealing ulcer disease. The thrombotic events primarily involved the microvasculature, with thrombosis of large vessels occurring far less frequently. We present an eighty-three year-old male patient suffering from bilateral lower extremity ulcers and pain. The underlying mechanism of his nonhealing ulcer is due to the essential thrombocythemia diagnosed during the admission. The patient was discharged with medical treatment after the amputation of necrotic tissues.

Key Words: Essential Thrombocythemia, Cardiovascular Surgery, Extremity Ulcer

Diyabet, venöz hastalıklar ve arteryal hastalıklar alt ekstremite ülserlerinin önemli bir kısmını olușturur. Aynı zamanda, iyileșmeyen ülser hastalıklarında esansiyel trombositemi nadir görülen bir nedendir. Esansiyel trombositemide trombotik olaylar özellikle küçük damarlar ve kapiller damarlarda görülürken büyük damarlarda trombotik olaylar nadirdir. Seksen üç yașında her iki alt ekstremitede ülser ve ağıı șikayetleri olan bir hastayı bildirdik. İyileșmeyen ülserin altta yatan mekanizması bașvuru sırasında tanı konulan esansiyel trombositemiye bağlıydı. Hasta nekrotik dokular ampute edildikten sonra medikal tedavisi düzenlenerek taburcu edildi.

Anahtar Sözcükler: Esansiyel Trombositemi, Kardiyovasküler Cerrahi, Eksremite Ülseri

Peripheral extremity ulcers affect patient's quality of life and productivity and represent a substantial financial burden on the health care system (1). Lower extremity ulcers, especially those attributed to diabetes, venous disease or arterial disease comprise a substantial proportion of chronic ulcers. Identifying ulcer cause is an important factor determining appropriate wound care intervention. Nonhealing ulcers are typically categorized as diabetic, venous or arterial. But the other factors can sometimes be overlooked.

Standard treatment of nonhealing ulcer is debridement of necrotic tissue, revascularization surgery, infection control, mechanical offloading, management of blood glucose, foot care education, mechanical compression or limb elevation (2). True diagnosis is the most important factor for the true treatment.

We present an eighty-three year-old male patient suffering bilateral lower extremity ulcers and diagnosed an essential thrombocythemia.

\section{CASE}

An eighty-three year-old male patient admitted to cardiovascular department complaning of bilateral toe ulcers and toe pain. Bilateral distal arterial systems were pulsatile on the physical examination. Left $4^{\text {th }}$ toe and right $3^{\text {rd }}$ and $5^{\text {th }}$ toes were necrotic (Figure 1). On the laboratory tests; blood glucose $73 \mathrm{mg} / \mathrm{dl}$, creatinine $1,48 \mathrm{mg} / \mathrm{dl}$, potassium 5,2 $\mathrm{mEq} / \mathrm{L}$, C-reactive protein 43,9 $\mathrm{mg} / \mathrm{L}$, sedimantation 


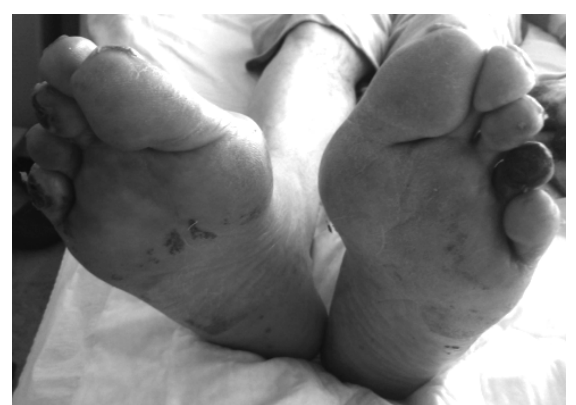

Figure 1: Left $4 \mathrm{t}^{\mathrm{n}}$ toe and right $3^{\text {rd }}$ and $5^{\text {th }}$ toes were necrotic due to the essential thrombocytopenia.

rate $38 \mathrm{IU} / \mathrm{ml}$, lycosite $18,6 \mathrm{~K} / \mathrm{mm}^{3}$, RBC 5,44 M/ $\mathrm{mm}^{3}$, thrombocyte 1065 $\mathrm{K} / \mathrm{mm}^{3}$, hemoglobin $11,7 \mathrm{~g} / \mathrm{dl}$ were observed. Lower extremity arterial systems revealed triphasic flow pattern on doppler ultrasonography. The magnetic resonance imaging (MRI) angiography demonstrated the patency of lower extremity arterial system without any sign of osteomyelitis (Figure 2). The patient was consulted with orthopedics and hematology clinics.. JAK2 and V617F mutations were positive on the hematology tests. All of them the patient was diagnosed essantial thorombocythemia. Acetylsalicylic acid $100 \mathrm{mg}$ per a day and hydroxyurea 500 $\mathrm{mg}$ three times a day was started. Also, oral iron preparation was started for iron deficiency anemia. After the medical treatment was created, necrotic finger amputeted. The postoperative period was uneventful and he was discharged on the 18. postoperative day. After six months later of the operation, patient admitted to our clinic for control and there was not any new lesion on extremity and amputated tissue was completely normal.

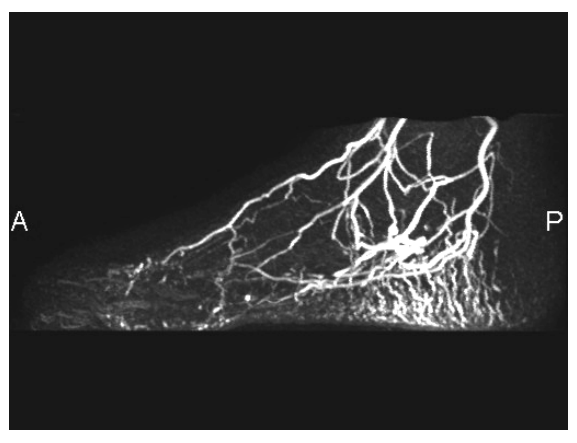

Figure 2: Magnetic resonance imaging (MRI) angiography of the patient's lower extremity arterial system revealed no obstructin or stenosis.

\section{DISCUSSION}

The presenting symptoms of patients with essential thrombocythemia are quite variable. After detection of thrombocytosis about 13 to 37 percent of patients relate symptoms due to hemorrhagic events, and about 22 to 84 percent of patients report thromboembolic complications. The thrombotic events primarily involved the microvasculature, with thrombosis of large vessels occurring far less frequently (3). Microvascular occlusions involving the toes and fingers are frequent. In our case we present a patient with pain and peripheral gangrene. Carobbio and et al. reported \%69 arterial event, \%31 venous thrombosis and \%3,6 major hemorrhagic events in their study $(4,5)$. Many factors may be resulted in nonhealing ulcer and extremity gangrene (Table 1). Cardiovascular surgeons must be careful in diagnosis for the true treatment. In our case laboratory and radiological data enabled to achieve a correct diagnosis. After the correct diagnosis, accurate treatment was performed. In the medical treatment $100 \mathrm{mg} /$ day acetylsalicylic acid and $1500 \mathrm{mg} /$ day hydroxyurea were started. Following the medical treatment, necrotic toes were amputated. However, latest studies presented that hydroxyurea plus low-dose acetylsalicylic acid was superior to anagrelide plus low-dose acetylsalicylic acid for patients with essential thrombocythemia for vascular events (6). In a nutshell, cardiac surgeons should be careful differential diagnosis for lower extremity ulcers and gangrene.

Table 1: Factors involved in nonhealing wounds.

\begin{tabular}{|l|}
\hline Factors involved in nonhealing wounds \\
\hline A.Local factors \\
-Infection \\
-Tissue maceration \\
-Foreign bodies \\
-Smoking \\
-Ischemia \\
-Local cancer (ie, basal cell cancer, squamous cell cancer,malignant melanoma) \\
-Venous insufficiency \\
-Mechanical Trauma (ie, pressure sores) \\
-Toxins \\
-Radiation \\
-latrogenic \\
\hline B.Systemic factors \\
-Chronic diseases (ie, diabetes mellitus, renal disease) \\
-Nutritional deficiencies (ie, deficiency in proteins, vitamins,minerals) \\
-Congenital healing disorders (ie, Epidermolisis Bullosa,Ehlers-Danlos syndrome, Marfan's syndrome) \\
-Alcoholism \\
-Glucocorticoid steroids \\
-Chemotherapeutic drugs (ie, methotrexate,cyclophosphamide, doxorubicin) \\
-Advanced age \\
-Distant cancer \\
-Uremia
\end{tabular}




\section{REFERENCES}

1. Greer N, Foman NA, Donanld RM, et al. Advanced Wound Care Therapies for Nonhealing Diabetic, Venous and Arterial Ulcers: Ann Intern Med. 2013;159:532-542

2. Ayello EA. What does the wound say? Why determining etiology is essential for appropriate wound care. Adv Skin Wound Care. 2005;18:98-109
3. Mozahep Z. Thromboembolic complication in essential thrombocythemia. Pan Afr Med J. 2012; 13: 58 .

4. Carobbio A, Finazzi G, Antonioli E, et al. Thrombocytosis and leukocytosis interaction in vascular complications of essential thrombocythemia. Blood Journal. 2008;112:8.
5. H. A. Keskin, F. Yetisir, H. Bayram et al., "Celiac artery thrombosis and superior mesenteric artery stenoses with essential thrombocythemia: a case report," Case Reports in Medicine, vol. 2012, Article ID741653, 3 pages, 2012.

6. Schölzel BE, Endeman H, Dewilde W, et al. Cardiac surgery in a patient with essential thrombocythemia: a case report. Netherlands Heart Journal. 2010;18:7-8. 
